\section{C-reactive protein as a marker of infection in children with severe acute malnutrition in Khartoum state, Sudan}

\author{
Abdelmoneim E.M. Kheir, \\ Balla G. Gebreel \\ Department of Paediatrics and Child \\ Health, University of Khartoum and \\ Soba University Hospital, Khartoum, \\ Sudan
}

\begin{abstract}
Severe acute malnutrition and acute systemic infection are often synergistic in children and lead to considerable mortality. The main aim of this research was to determine whether children with severe acute malnutrition can mount an acute phase reactant response measured by C-reactive protein. This was a descriptive, cross-sectional, hospital-based study that was carried out in the five main children hospitals in Khartoum state, from November 1 $1^{\text {st }}, 2012$ to March 1 ${ }^{\text {st }}, 2013.132$ children with severe acute malnutrition were included in the study. Data collection included history, examination and C-reactive protein measurement. The data were analyzed using Statistical Package for Social Sciences (SPSS) for descriptive and inferential statistics. The main results revealed that 93(70.5\%) children between 12-23 months of age and most of them had marasmus. Diarrhoea was the commonest presenting symptoms in $86.4 \%$, followed by fever and vomiting. Most of the children (82.6\%) had positive C-reactive protein with variable levels. In conclusion malnourished children are able to synthesize C-reactive protein in response to an infectious process and the magnitude of this response is increased in those with severe infections.
\end{abstract}

\section{Introduction}

Malnutrition remains one of the most common causes of morbidity and mortality among children throughout the world. It is estimated that, in developing countries, more than one-quarter of all children younger than 5 years of age are malnourished. ${ }^{1}$ Malnutrition diminishes immune function and prevents the host from mounting an adequate protective response to infectious agents. In turn, infections alter nutrient status and can create a deficiency state. Thus, malnutrition and infection often act synergistically to increase morbidity and mortality, particularly among infants and children. $^{2}$

Several studies on the effect of malnutrition at the immunological level have been carried out with humans and experimental animals. These studies indicate that malnutrition decreases T-cell function, cytokine production, and the ability of lymphocytes to respond appropriately to cytokines. ${ }^{3}$

The usual signs of infection are absent or nonspecific in children with acute severe malnutrition (SAM), Furthermore, laboratory diagnostic capacity is often limited in regions with the highest burdens of malnutrition. Consequently, treatment is empirical. ${ }^{4,5}$ Malnourished patients maintain the capacity to release inflammatory markers such as CRP \& IL-6 which can be considered favorable for combating infections. ${ }^{6}$

There are very few studies that have investigated the role of $\mathrm{C}$ reactive protein (CRP) as a diagnostic tool of infection in African children where infection profiles are different. ${ }^{7,8}$ This is further complicated by the fact that SAM, particularly edematous malnutrition, can be associated with reduced levels of acute phase proteins. ${ }^{9}$

The main objectives of this study were to determine whether children with SAM can mount an acute phase reactant response namely CRP and to evaluate the usefulness of quantitative CRP as a predictor of severe infections in children with SAM.

\section{Materials and Methods}

This was a prospective, cross-sectional, hospital-based study that was carried out in the five main children hospitals in Khartoum state, during the period 1.11.2012 to 1.32013 (change this date format). All children aged 6-59 months who were admitted with the diagnosis of SAM during their first three days of admission were included in the study. 132 children with SAM were recruited to participate in the study. The diagnosis of SAM was made using the recent WHO criteria measuring weight for length/height and mid-upper arm circumference (MUAC) and the presence of bilateral pitting oedema and severe wasting. Two forms of SAM exist in children: nonoedematous malnutrition, also known as marasmus, characterized by severe wasting and currently defined by weight for length/height $\mathrm{z}$ score $<-3$ of the WHO growth standard, or MUAC $<11.5 \mathrm{~cm}$; and oedematous malnutrition defined by bilateral pitting oedema also known as Kwashiorkor. ${ }^{10}$ The term marasmic kwashiorkor, has been used to describe children with both wasting and oedema. ${ }^{11}$
Correspondence: Abdelmoneim E.M. Kheir, Department of Paediatrics and Child Health, Faculty of Medicine, University of Khartoum and Soba University Hospital, P.O. Box 102, Khartoum, Sudan.

Tel: +249 912313110 - Fax +249 183776295

E-mail: moneimkheir62@hotmail.com

Acknowledgements: the authors express their sincere gratitude to the administrations of the five hospitals in Khartoum state for giving their permission to conduct this research. Thanks are also extended to the caregivers of the children who participated willingly.

Key words: Malnutrition; Marasmus; Kwashiorkor C-reactive protein; Infection.

Conflict of interest: the authors declare no potential conflict of interest.

Contributions: the authors contributed equally, all authors read and approved the final manuscript.

Funding: there was no research grant for this study.

Received for publication: 21 November 2016 Accepted for publication: 2 February 2017.

This work is licensed under a Creative Commons Attribution 4.0 License (by-nc 4.0).

(C) Copyright A.E.M. Kheir and B.G. Gebreel, 2017 Licensee PAGEPress, Italy

Healthcare in Low-resource Settings 2017; 5:6401 doi:10.4081/hls.2017.6401

Children with malnutrition secondary to serious underlying conditions including congenital anomalies, inborn errors of metabolism, malignancies, inherited autosomal disorders like cystic fibrosis, chronic diarrheal diseases like caeliac disease, congenital cardiac diseases, chronic kidney disease were excluded from the study.

All children underwent detailed history and clinical examination by a senior member of the staff (registrar, consultant), personal details were recorded like age, sex, residence, symptoms and signs of sepsis, bilateral pitting oedema and visible severe wasting. Anthropometric measurements were taken namely weight, length or height and MUAC.

All those who were enrolled in this study, underwent blood sampling: (two milliliters of blood were drawn from a peripheral vein under aseptic condition after cleaning the skin with $70 \%$ alcohol), then the serum was separated and sent for CRP measurement, using the latex agglutination test and patients were put into 5 groups according to CRP level: ${ }^{12,13}$ level less than $10 \mathrm{mg} / \mathrm{L}$, regarded as normal; level from 
$10-20 \mathrm{mg} / \mathrm{L}$, regarded as elevated; level from $20-50 \mathrm{mg} / \mathrm{L}$, may rule out serious bacterial infections; level from $50-100 \mathrm{mg} / \mathrm{L}$, suggests bacterial infections; level exceeding $100 \mathrm{mg} / \mathrm{L}$, suggests serious bacterial infections.

Other routine investigations were also done like stool analysis, urinalysis, random blood sugar, complete blood count, renal function test and electrolytes. CXR was done where applicable. Blood culture was done on few patients because it is not always available. The data was analyzed using the statistical package for social sciences (SPSS) version 20 for descriptive and inferential statistics. Chi-square test was used to test for significant association between SAM and the following independent variables (age, sex, residence, MUAC, weight for height). Also, the association of CRP level and serious infections was studied. $P$ value of less than 0.05 was considered significant.

Ethical clearance and approval for conducting this research was obtained from the ethical committee of the Sudan medical specialization board. Prior informed consent was obtained from the caregivers of the individual subjects.

\section{Results}

A total of 132 children with SAM were included in this study. There were 76 $(57.6 \%)$ males and $56(42.4 \%)$ females, the male: female ratio was $1.36: 1$. The study revealed that $93(70.5 \%)$ children were 12 23 months of age , 34(25.8\%) between 2436 months and only $5(3.7 \%)$ between $36-59$ months. Most of the children had marasmus and were lying between the age group 1223 months with significant association between age and type of SAM $(\mathrm{P}=0.006)$ (Table 1).

With regards to place of residence, $39(29.5 \%)$ were living in urban areas where as $93(70.5 \%)$ live in periurban areas with no significant association between place of residence and type of SAM $(\mathrm{P}=0.072)$ (Table 2). $70(53 \%)$ of the total participants had marasmus, 39 (29.5\%) had kwashiorkor and $23(17.4 \%)$ had marasmic-kwashiorkor. Regarding the presenting symptoms of the study population, $89(67.4 \%)$ children had fever, $71(53.8 \%)$ had poor appetite, 114 (86.4\%) had diarrhea, 83 (62.9\%) had vomiting, $100(75.8 \%)$ had weight loss, 48 (36.4\%) had cough, 4 (3.0\%) had sore throat, 3 (2.3\%) had ear discharge, 18 $(13.6 \%)$ had skin lesions. $2(1.5 \%)$ had burning micturition, $96(72.7 \%)$ had pallor, $62(47.0 \%)$ had oedema, and $3(2.3 \%)$ had convulsions. Therefore diarrhea was the
Table 1. Distribution of the study population according to age and type of severe acute malnutrition.

\begin{tabular}{llcccc} 
Agge in months & \multicolumn{3}{c}{ Disease } & Total \\
& & M & MK & $\mathrm{K}$ & \\
\multirow{3}{*}{12 up to 23 } & Count & 41 & 18 & 34 & 93 \\
& \% within Age & 44.1 & 19.4 & 36.6 & 100.0 \\
& \% within Disease & 58.6 & 78.3 & 87.2 & 70.5 \\
& \% of Total & 31.1 & 13.6 & 25.8 & 70.5 \\
\multirow{3}{*}{24 up to 36 } & Count & 27 & 3 & 4 & 34 \\
& \% within Age & 79.4 & 8.8 & 11.8 & 100.0 \\
& \% within Disease & 38.6 & 13.0 & 10.3 & 25.8 \\
& \% of Total & 20.5 & 2.3 & 3.0 & 25.8 \\
\hline \multirow{3}{*}{36 up to 59 } & Count & 2 & 2 & 1 & 5 \\
& \% within Age & 40.0 & 40.0 & 20.0 & 100.0 \\
& \% within Disease & 2.9 & 8.7 & 2.6 & 3.7 \\
Total & \% of Total & 1.5 & 1.5 & .8 & 3.7 \\
& Count & 70 & 23 & 39 & 132 \\
& \% within Age & 53.0 & 17.4 & 29.5 & 100.0 \\
& \% within Disease & 100.0 & 100.0 & 100.0 & 100.0 \\
& \% of Total & 53.0 & 17.4 & 29.5 & 100.0 \\
\hline
\end{tabular}

M, Marasmus; K, Kwashiorkor; MK, Marasmic-Kwashiorkor.

Table 2. Distribution of study population according to residence and type of severe acute malnutrition.

\begin{tabular}{|c|c|c|c|c|c|c|}
\hline \multirow[t]{2}{*}{ Age in months } & & & \multicolumn{3}{|c|}{ Disease } & \multirow[t]{2}{*}{ Total } \\
\hline & & & M & MK & K & \\
\hline \multirow[t]{8}{*}{ Residence } & Urban & Count & 20 & 11 & 8 & 39 \\
\hline & & $\%$ within residence & 51.3 & 28.2 & 20.5 & 100.0 \\
\hline & & $\%$ within Disease & 28.6 & 47.8 & 20.5 & 29.5 \\
\hline & & $\%$ of Total & 15.2 & 8.3 & 6.1 & 29.5 \\
\hline & Peri Urban & Count & 50 & 12 & 31 & 93 \\
\hline & & $\%$ within residence & 53.8 & 12.9 & 33.3 & 100.0 \\
\hline & & $\%$ within Disease & 71.4 & 52.2 & 79.5 & 70.5 \\
\hline & & $\%$ of Total & 37.9 & 9.1 & 23.5 & 70.5 \\
\hline \multirow[t]{4}{*}{ Total } & & Count & 70 & 23 & 39 & 132 \\
\hline & & $\%$ within residence & 53.0 & 17.4 & 29.5 & 100.0 \\
\hline & & $\%$ within Disease & 100.0 & 100.0 & 100.0 & 100.0 \\
\hline & & $\%$ of Total & 53.0 & 17.4 & 29.5 & 100.0 \\
\hline
\end{tabular}

M, Marasmus; K, Kwashiorkor; MK, Marasmic-Kwashiorkor.

Table 3. Relation between mid-upper arm circumference and type of severe acute malnutrition.

\begin{tabular}{llcccc}
\hline MUAC & & & Disease & Total \\
\multirow{3}{*}{$<11.5 \mathrm{~cm}$} & & M & MK & \\
& Count & 44 & 11 & 28 & 83 \\
& \% within MUAC & 53.0 & 13.3 & 33.7 & 100.0 \\
& \% within Disease & 62.9 & 47.8 & 71.8 & 62.9 \\
& \% of Total & 33.3 & 8.3 & 21.2 & 62.9 \\
\hline \multirow{3}{*}{$11.5-12.5 \mathrm{~cm}$} & Count & 24 & 11 & 9 & 44 \\
& \% within MUAC & 54.5 & 25.0 & 20.5 & 100.0 \\
& \% within Disease & 34.3 & 47.8 & 23.1 & 33.3 \\
& \% of Total & 18.2 & 8.3 & 6.8 & 33.3 \\
\hline \multirow{2}{*}{$12.5 \mathrm{~cm}$} & Count & 2 & 1 & 2 & 5 \\
& \% within MUAC & 40.0 & 20.0 & 40.0 & 100.0 \\
& \% within Disease & 2.9 & 4.3 & 5.1 & 3.8 \\
Total & \% of Total & 1.5 & .8 & 1.5 & 3.8 \\
& Count & 70 & 23 & 39 & 132 \\
& \% within MUAC & 53.0 & 17.4 & 29.5 & 100.0 \\
& \% within Disease & 100.0 & 100.0 & 100.0 & 100.0 \\
& \% of Total & 53.0 & 17.4 & 29.5 & 100.0 \\
\hline
\end{tabular}

MUAC, mid-upper arm circumference; M, Marasmus; K, Kwashiorkor; MK, Marasmic-Kwashiorkor. 
most common presenting symptom (86.4\%), while burning micturition was the least common (1.5\%).

The study showed that in $83(62.9 \%)$ children MUAC was below $11.5 \mathrm{~cm}$, out of these $44(33.3 \%)$ had marasmus, $11(8.3 \%)$ marasmic-kwashiorkor and $28(21.2 \%)$ had kwashiorkor, with no significant association between MUAC and type of SAM ( $\mathrm{P}=$ 0.356) (Table 3).

When considering weight for length/height, 86 cases $(65.2 \%)$ had their weight for length/height less than -3SD, of whom 69 cases $(52 \%)$ were marasmic, and 17 (12.9\%) marasmic-kwashiorkor, and there was significant association between weight for length/height and $\operatorname{SAM}(\mathrm{P}=0.00)$ (Table 4).

All participants were subjected to quantitative CRP measurement. 45 (34.1\%) cases had CRP less than $10 \mathrm{mg} / \mathrm{L}, 32$ (24.2\%) cases had CRP level between 10$20 \mathrm{mg} / \mathrm{L}, 22(16.7 \%)$ cases had CRP level between $21-50 \mathrm{mg} / \mathrm{L}, 15$ (11.4\%) cases had CRP level between $51-100 \mathrm{mg} / \mathrm{L}$ and 18 cases (13.6\%) had CRP level more than 100 $\mathrm{mg} / \mathrm{L}$, of whom 11 cases $(8.3 \%)$ marasmus, $5(3.8 \%)$ kwashiorkor and $2(1.5 \%)$ marasmic-kwashiorkor. The study revealed no significant association between CRP level and type of SAM $(\mathrm{P}=0.341)$ (Table 5).

Out of these 18 cases with CRP more than $100 \mathrm{mg} / \mathrm{L}, 3(2.3 \%)$ cases had extensive infected skin lesions, 4 (3\%)cases had pneumonia based on X-ray. 4(3\%) had gastroenteritis, $2(1.5 \%)$ cases had severe sepsis, both had blood cultures taken, in one sample the result was contaminated and the parents refused a repeat sample. In the second sample klebsiella species was isolated. 1 case had urinary tract infection. 2 cases out of the 18 refused to continue after the result of CRP, while the remaining 2 discharged themselves against medical advice. There was significant association between CRP level and serious infections (Table 6) $(\mathrm{P}=0.000)$.

\section{Discussion}

Severe malnutrition and acute systemic infection are often synergistic in children. ${ }^{14}$ In the present study an attempt has been made to see whether children with SAM can mount an acute phase reactant response, namely CRP and to evaluate the usefulness of quantitative CRP as a predictor of severe infections in children with SAM. Our data indicated that most of the children $(70.5 \%)$ were less than two years of age which is quite compatible with other reports from developing countries. ${ }^{15,16}$

Our study showed that diarrhoea was the commonest presenting symptoms in $86.4 \%$, followed by fever and vomiting which is quite similar to the statistics of African and Asian countries though our figure is slightly higher. ${ }^{17}$ It is stated that most children with severe protein-energy malnutrition have asymptomatic infections because their immune system fails to respond with chemotaxis, opsonization and phagocytosis of bacteria, viruses or fungi, however this is not the finding in our study. ${ }^{18}$

Our data indicated that most of the children with SAM $(82.6 \%)$ had positive CRP with variable levels and most of them were marasmus or marasmic-kwashiorkor, this

Table 4. Relation between weight for height/length and type of severe acute malnutrition.

\begin{tabular}{|c|c|c|c|c|c|}
\hline \multirow{2}{*}{\multicolumn{2}{|c|}{ Weight for height/length }} & \multicolumn{3}{|c|}{ Disease } & \multirow[t]{2}{*}{ Total } \\
\hline & & M & MK & $\mathrm{K}$ & \\
\hline \multirow[t]{4}{*}{-1 to -2 SD } & Count & 0 & 1 & 7 & 8 \\
\hline & \% within Wt.For.height & 0.0 & 12.5 & 87.5 & 100.0 \\
\hline & $\%$ within Disease & 0.0 & 4.3 & 17.9 & 6.1 \\
\hline & $\%$ of Total & 0.0 & 0.8 & 5.3 & 6.1 \\
\hline \multirow[t]{4}{*}{-2 to -3 SD } & Count & 1 & 5 & 32 & 38 \\
\hline & \% within Wt.For.height & 2.6 & 13.2 & 84.2 & 100.0 \\
\hline & $\%$ within Disease & 1.4 & 21.7 & 82.1 & 28.8 \\
\hline & $\%$ of Total & 0.8 & 3.8 & 24.2 & 28.8 \\
\hline \multirow{4}{*}{$<-3 \mathrm{SD}$} & Count & 69 & 17 & 0 & 86 \\
\hline & \% within Wt.For.height & 80.2 & 19.8 & 0.0 & 100.0 \\
\hline & $\%$ within Disease & 98.6 & 73.9 & 0.0 & 65.2 \\
\hline & $\%$ of Total & 52.3 & 12.9 & 0.0 & 65.2 \\
\hline \multirow[t]{4}{*}{ Total } & Count & 70 & 23 & 39 & 132 \\
\hline & \% within Wt.For.height & 53.0 & 17.4 & 29.5 & 100.0 \\
\hline & $\%$ within Disease & 100.0 & 100.0 & 100.0 & 100.0 \\
\hline & $\%$ of Total & 53.0 & 17.4 & 29.5 & 100.0 \\
\hline
\end{tabular}

SD, standard deviation; M, Marasmus; K, Kwashiorkor; MK, Marasmic-Kwashiorkor.

Table 5. Relation of C-reactive protein with type of severe acute malnutrition.

\begin{tabular}{|c|c|c|c|c|c|}
\hline \multirow[t]{2}{*}{ CRP } & & \multicolumn{3}{|c|}{ Disease } & \multirow[t]{2}{*}{ Total } \\
\hline & & M & MK & K & \\
\hline$-<10 \mathrm{mg} / \mathrm{L}$ & $\begin{array}{l}\text { Count } \\
\text { \% within CRP } \\
\% \text { within disease } \\
\% \text { of total }\end{array}$ & $\begin{array}{c}27 \\
60.0 \\
38.6 \\
20.5\end{array}$ & $\begin{array}{c}14 \\
31.1 \\
35.9 \\
10.6\end{array}$ & $\begin{array}{c}4 \\
8.9 \\
17.4 \\
3.0\end{array}$ & $\begin{array}{c}45 \\
100.0 \\
34.1 \\
34.1\end{array}$ \\
\hline $10-20$ mg/L & $\begin{array}{l}\text { Count } \\
\% \text { within CRP } \\
\% \text { within disease } \\
\% \text { of total }\end{array}$ & $\begin{array}{c}12 \\
37.5 \\
17.1 \\
9.1 \\
\end{array}$ & $\begin{array}{c}12 \\
37.5 \\
30.8 \\
9.1\end{array}$ & $\begin{array}{c}8 \\
25.0 \\
34.8 \\
6.1\end{array}$ & $\begin{array}{c}32 \\
100.0 \\
24.2 \\
24.2\end{array}$ \\
\hline $20-50$ mg/L & $\begin{array}{l}\text { Count } \\
\% \text { within CRP } \\
\% \text { within disease } \\
\% \text { of total }\end{array}$ & $\begin{array}{c}13 \\
59.1 \\
18.6 \\
9.8\end{array}$ & $\begin{array}{c}6 \\
27.3 \\
15.4 \\
4.5\end{array}$ & $\begin{array}{c}3 \\
13.6 \\
13.0 \\
2.3\end{array}$ & $\begin{array}{c}22 \\
100.0 \\
16.7 \\
16.7\end{array}$ \\
\hline $50-100 \mathrm{mg} / \mathrm{L}$ & $\begin{array}{l}\text { Count } \\
\% \text { within CRP } \\
\% \text { within disease } \\
\% \text { of total }\end{array}$ & $\begin{array}{c}7 \\
46.7 \\
10.0 \\
5.3\end{array}$ & $\begin{array}{c}2 \\
13.3 \\
5.1 \\
1.5\end{array}$ & $\begin{array}{c}6 \\
40.0 \\
26.1 \\
4.5\end{array}$ & $\begin{array}{c}15 \\
100.0 \\
11.4 \\
11.4\end{array}$ \\
\hline$>100$ mg/L & $\begin{array}{l}\text { Count } \\
\% \text { within CRP } \\
\% \text { within disease } \\
\% \text { of total }\end{array}$ & $\begin{array}{c}11 \\
61.1 \\
15.7 \\
8.3\end{array}$ & $\begin{array}{c}5 \\
27.8 \\
12.8 \\
3.8\end{array}$ & $\begin{array}{c}2 \\
11.1 \\
8.7 \\
1.5\end{array}$ & $\begin{array}{c}18 \\
100.0 \\
13.6 \\
13.6\end{array}$ \\
\hline Total & $\begin{array}{l}\text { Count } \\
\% \text { within CRP } \\
\% \text { within disease } \\
\% \text { of total }\end{array}$ & $\begin{array}{c}70 \\
53.0 \\
100.0 \\
53.0\end{array}$ & $\begin{array}{c}39 \\
29.5 \\
100.0 \\
29.5\end{array}$ & $\begin{array}{c}23 \\
17.4 \\
100.0 \\
17.4\end{array}$ & $\begin{array}{c}132 \\
100.0 \\
100.0 \\
100.0\end{array}$ \\
\hline
\end{tabular}

$\mathrm{P}=0.135$

CRP, C-reactive protein; M, Marasmus; K, Kwashiorkor; MK, Marasmic-Kwashiorkor. 
Table 6. Relation of C-reactive protein matching the level of serious infections with diagnosis.

\begin{tabular}{|c|c|c|c|c|c|c|c|c|}
\hline & & None & $\begin{array}{l}\text { Clinical } \\
\text { diagnosis }\end{array}$ & $\begin{array}{l}\text { Based on } \\
\text { Chest } \\
\text { X-ray }\end{array}$ & $\begin{array}{l}\text { Stool } \\
\text { analysis \& culture }\end{array}$ & $\begin{array}{l}\text { Blood } \\
\text { culture }\end{array}$ & Urinalysis & Total \\
\hline Infected skin lesions & $\begin{array}{l}\text { Count } \\
\% \text { within Diagnosis } \\
\% \text { within Bass on } \\
\% \text { of Total }\end{array}$ & $\begin{array}{c}0 \\
0.0 \\
0.0 \\
0.0\end{array}$ & $\begin{array}{c}3 \\
100.0 \\
100.0 \\
16.7\end{array}$ & $\begin{array}{c}0 \\
0.0 \\
0.0 \\
0.0\end{array}$ & $\begin{array}{c}0 \\
0.0 \\
0.0 \\
0.0\end{array}$ & $\begin{array}{c}0 \\
0.0 \\
0.0 \\
0.0\end{array}$ & $\begin{array}{c}0 \\
0.0 \\
0.0 \\
0.0\end{array}$ & $\begin{array}{c}3 \\
100.0 \\
16.7 \\
16.7\end{array}$ \\
\hline Pneumonia & $\begin{array}{l}\text { Count } \\
\text { \% within Diagnosis } \\
\% \text { within Bass on } \\
\% \text { of Total }\end{array}$ & $\begin{array}{c}0 \\
0.0 \\
0.0 \\
0.0\end{array}$ & $\begin{array}{c}0 \\
0.0 \\
0.0 \\
0.0\end{array}$ & $\begin{array}{c}4 \\
100.0 \\
100.0 \\
22.2\end{array}$ & $\begin{array}{c}0 \\
0.0 \\
0.0 \\
0.0\end{array}$ & $\begin{array}{c}0 \\
0.0 \\
0.0 \\
0.0\end{array}$ & $\begin{array}{c}0 \\
0.0 \\
0.0 \\
0.0\end{array}$ & $\begin{array}{c}4 \\
100.0 \\
22.2 \\
22.2\end{array}$ \\
\hline Gastroenteritis & $\begin{array}{l}\text { Count } \\
\text { \% within Diagnosis } \\
\text { \% within Bass on } \\
\% \text { of Total }\end{array}$ & $\begin{array}{c}0 \\
0.0 \\
0.0 \\
0.0\end{array}$ & $\begin{array}{c}0 \\
0.0 \\
0.0 \\
0.0\end{array}$ & $\begin{array}{c}0 \\
0.0 \\
0.0 \\
0.0\end{array}$ & $\begin{array}{c}4 \\
100.0 \\
100.0 \\
22.2\end{array}$ & $\begin{array}{c}0 \\
0.0 \\
0.0 \\
0.0\end{array}$ & $\begin{array}{c}0 \\
0.0 \\
0.0 \\
0.0\end{array}$ & $\begin{array}{c}4 \\
100.0 \\
22.2 \\
22.2\end{array}$ \\
\hline Sepsis & $\begin{array}{l}\text { Count } \\
\text { \% within Diagnosis } \\
\% \text { within Bass on } \\
\% \text { of Total }\end{array}$ & $\begin{array}{c}0 \\
0.0 \\
0.0 \\
0.0\end{array}$ & $\begin{array}{c}0 \\
0.0 \\
0.0 \\
0.0\end{array}$ & $\begin{array}{c}0 \\
0.0 \\
0.0 \\
0.0\end{array}$ & $\begin{array}{c}0 \\
0.0 \\
0.0 \\
0.0\end{array}$ & $\begin{array}{c}2 \\
100.0 \\
100.0 \\
11.1\end{array}$ & $\begin{array}{c}0 \\
0.0 \\
0.0 \\
0.0\end{array}$ & $\begin{array}{c}2 \\
100.0 \\
11.1 \\
11.1\end{array}$ \\
\hline U.T.I & $\begin{array}{l}\text { Count } \\
\text { \% within Diagnosis } \\
\% \text { within Bass on } \\
\% \text { of Total }\end{array}$ & $\begin{array}{c}0 \\
0.0 \\
0.0 \\
0.0\end{array}$ & $\begin{array}{c}0 \\
0.0 \\
0.0 \\
0.0\end{array}$ & $\begin{array}{c}0 \\
0.0 \\
0.0 \\
0.0\end{array}$ & $\begin{array}{c}0 \\
0.0 \\
0.0 \\
0.0\end{array}$ & $\begin{array}{c}0 \\
0.0 \\
0.0 \\
0.0\end{array}$ & $\begin{array}{c}1 \\
100.0 \\
100.0 \\
5.6\end{array}$ & $\begin{array}{c}1 \\
100.0 \\
5.6 \\
5.6\end{array}$ \\
\hline DAMA & $\begin{array}{l}\text { Count } \\
\% \text { within Diagnosis } \\
\% \text { within Bass on } \\
\% \text { of Total }\end{array}$ & $\begin{array}{c}2 \\
100.0 \\
50.0 \\
11.1\end{array}$ & $\begin{array}{c}0 \\
0.0 \\
0.0 \\
0.0\end{array}$ & $\begin{array}{c}0 \\
0.0 \\
0.0 \\
0.0\end{array}$ & $\begin{array}{c}0 \\
0.0 \\
0.0 \\
0.0\end{array}$ & $\begin{array}{c}0 \\
0.0 \\
0.0 \\
0.0\end{array}$ & $\begin{array}{c}0 \\
0.0 \\
0.0 \\
0.0\end{array}$ & $\begin{array}{c}2 \\
100.0 \\
11.1 \\
11.1\end{array}$ \\
\hline Refused to continue & $\begin{array}{l}\text { Count } \\
\text { \% within Diagnosis } \\
\% \text { within Bass on } \\
\% \text { of Total }\end{array}$ & $\begin{array}{c}2 \\
100.0 \\
50.0 \\
11.1\end{array}$ & $\begin{array}{c}0 \\
0.0 \\
0.0 \\
0.0\end{array}$ & $\begin{array}{c}0 \\
0.0 \\
0.0 \\
0.0\end{array}$ & $\begin{array}{c}0 \\
0.0 \\
0.0 \\
0.0\end{array}$ & $\begin{array}{c}0 \\
0.0 \\
0.0 \\
0.0\end{array}$ & $\begin{array}{c}0 \\
0.0 \\
0.0 \\
0.0\end{array}$ & $\begin{array}{c}2 \\
100.0 \\
11.1 \\
11.1\end{array}$ \\
\hline Total & $\begin{array}{l}\text { Count } \\
\text { \% within Diagnosis } \\
\% \text { within Bass on } \\
\% \text { of Total }\end{array}$ & $\begin{array}{c}4 \\
22.2 \\
100.0 \\
22.2\end{array}$ & $\begin{array}{c}3 \\
16.7 \\
100.0 \\
16.7\end{array}$ & $\begin{array}{c}4 \\
22.2 \\
100.0 \\
22.2\end{array}$ & $\begin{array}{c}4 \\
22.2 \\
100.0 \\
22.2\end{array}$ & $\begin{array}{c}2 \\
11.1 \\
100.0 \\
11.1\end{array}$ & $\begin{array}{c}1 \\
5.6 \\
100.0 \\
5.6\end{array}$ & $\begin{array}{c}18 \\
100.0 \\
100.0 \\
100.0\end{array}$ \\
\hline
\end{tabular}

UTI, urinary tract infection; DAMA, discharged against medical advice.

indicates that children with SAM are able to synthesize CRP in response to infections and the magnitude is more $(>100 \mathrm{mg} / \mathrm{L})$ in those with severe infections, our finding is quite consistent with other similar studies which agreed that severely malnourished infected children are capable of increasing concentrations of CRP in response to infectious diseases. ${ }^{19,20}$

18 cases in our series had CRP level more than $100 \mathrm{mg} / \mathrm{L}$, of whom 11 cases had marasmus. Amesty-Valbuena et al. reported a similar finding as they found high CRP levels in children with marasmus. ${ }^{20}$ The weaker response in the edematous group is not surprising and can be explained by the fact that Children with kwashiorkor, however, differ from those with marasmus in having slower rates of whole-body protein breakdown, which may reduce the availability of endogenous amino acids for CRP synthesis. ${ }^{19}$ It is interesting that there is one study which found that CRP levels in response to infection are lower in malnourished than in well-nourished children. ${ }^{21}$

\section{Conclusions}

These results showed that malnourished children are able to synthesize CRP in response to an infectious process and the magnitude of this response is more in those with severe infections. High cost of other inflammatory markers precludes their clinical and routine application in low resource settings. Therefore, CRP being easily measurable and more affordable can be conveniently used as a good marker for the diagnosis of infection in children with SAM.

\section{References}

1. United Nations Administrative Committee on Coordination. 2000. Fourth report on the world nutrition situation. United Nations Administrative Committee on Coordination/SubCommittee on Nutrition, Geneva,

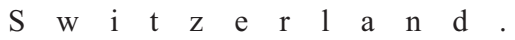
www.unscn.org/layout/modules/resourc es/files/rwns4.pdf

2. Calder PC, Jackson AA, Undernutrition, infection and immune function. Nutr Res Rev 2000;13:3-29.

3. Rodríguez L, González C, Flores L, et al. Assessment by flow cytometry of cytokine production in malnourished children. Clin Diagn Lab Immunol 2005;12:502-7.

4. Chisti MJ, Tebruegge M, La Vincente S, et al. Pneumonia in severely malnourished children in developing countries-mortality risk, aetiology and validity of WHO clinical signs: a systematic review. Trop Med Int Health 2009;14:1173-89.

5. Page AL, de Rekeneire N, Sayadi S, et al. Infections in children admitted with complicated severe acute malnutrition in Niger. PLoS ONE 2013;8:e68699.

6. Delgado AF, Okay TS, Leone C, et al. Hospital malnutrition and inflammatory response in critically ill children and adolescents admitted to a tertiary intensive care unit. Clinics (Sao Paulo) 
2008;63:357-62.

7. Carrol ED, Mankhambo LA, Jeffers G, et al. The diagnostic and prognostic accuracy of five markers of serious bacterial infection in Malawian children with signs of severe infection. PLoS One 2009;4:e6621.

8. Díez-Padrisa N, Bassat Q, Morais L, et al. Procalcitonin and $\mathrm{C}$-reactive protein as predictors of blood culture positivity among hospitalised children with severe pneumonia in Mozambique. Trop Med Int Health. 2012;17:1100-7.

9. Jahoor F, Badaloo A, Reid M, Forrester T. Protein metabolism in severe childhood malnutrition. Ann Trop Paediatr 2008;28:87-101.

10. World Health Organization, United Nations Children's Fund (2009). WHO child growth standards and the identification of severe acute malnutrition in infants and children. A Joint Statement. Available from: http://www.who. int/maternal_child_adolescent/documents/9789241598163/en/
11. Wellcome Trust Working Party. Classification of infantile malnutrition. Lancet 1970;8:302-3.

12. Melbye H, Stocks N. point of care testing for $\mathrm{C}$ - reactive protein, a new path for Australian GPs ? Aust Fam Physician 2006;35:523-6.

13. Gabay G, Kushner I. Acute phase proteins and other systemic responses to inflammation. N Eng J Med 1999;340: 448-54.

14. Scrimshaw NS, SanGiovanni J. Synergism of nutrition, infection and immunity: an overview. Am J Clin Nutr 1997;66:464S-77S.

15. Mahgoub HM, Adam I. Morbidity and Mortality of severe malnutrition among Sudanese Children in New Halfa Hospital, Eastern Sudan. Trans R Soc Trop Med Hyg 20121;06:66-8.

16. Muller O, Krawinkel M. Malnutrition and death in developing countries. CMAJ 2005; 173:279-86.

17. Bernal C, Velásquez C, Alcaraz G, Botero J. Treatment of severe malnutri- tion in children: experience in implementing the World Health Organization Guidelines in Turbo, Colombia. J Pediatr Gastroenter Nutr 2008;46:3228.

18. Bhan MK, Bhandari N, Bahl R. Management of the severely malnourished child: perspective from developing countries. BMJ 2003;326:146-51.

19. Manary MJ, Broadhead RL, Yaresheski KE. Whole-body protein kinetics in marasmus and kwashiorkor during acute infection. Am J Clin Nutr 1998; 67:1205-9.

20. Amesty-Valbuena A, Pereira N, Castillo $\mathrm{J}$, et al. Mediadores de inflamación (proteina $\mathrm{C}$ reactiva) en el niño con desnutrición proteico-energética y en el niño eutrófico. Invest Clin 2004;45:5362.

21. Manary MJ, Yarasheski KE, Berger R, et al. Wholebody leucine kinetics and the acute phase response during acute infection in marasmic Malawian children. Pediatr Res 2004;55:940-6. 